\title{
Pemberdayaan Masyarakat Desa: Sosialisasi Pembuatan Pupuk Organik Berbahan Baku Urin Ternak Sapi
}

\author{
Nur Ana Dwi Kusasih ${ }^{1}$, Ratna Puji Lestari ${ }^{2}$, Prasetyo Budi Darmono ${ }^{3^{*}}$ \\ Universitas Muhammadiyah Purworejo \\ Jl. KHA. Dahlan 3 dan 6 Purworejo, Jawa Tengah, Indonesia \\ *email: alkha.85@gmail.com
}

\begin{abstract}
Abstrak - Urin sapi belum banyak dikembangkan agar memiliki nilai manfaat. Urin dari ternak sapi memiliki beberapa kandungan, unsure hara seperti karbon $(C)$, oksigen $(O)$, hidrogen $(H)$, nitrogen $(N)$, fosfor $(P)$, kalium $(\mathrm{K})$, magnesium $(\mathrm{Mg})$, dan besi ( $\mathrm{Fe}$ ). Kandungan-kandungan tersebut sangat dibutuhkan bagi tanaman terlebih di desa Bonjoklor yang mayoritas pekerjaannya adalah bercocok tanam atau bertani. Tujuan dari kegiatan penyuluhan pembuatan pupuk organik dari urin sapi ini antara lain: 1) Mencegah pencemaran lingkungan karena urin yang tidak dimanfaatkan secara maksimal dapat menyebabkan berbagai macam penyakit seperti, desentri dan diare baik pada ternak maupun manusia. 2) Pemanfaatan limbah urin sapi membantu perekonomian masyarakat sekitar 3) Meningkatkan kesuburan tanah karena pupuk organik dari urin sapi mempunyai efek jangka panjang yang baik bagi tanah Desa Bonjoklor. Dalam pembuatan pupuk organik cair dari urin sapi ini menggunakan metode fermentasi kurang lebih selama 3 minggu. Kegiatan "Sosialisasi Pembuatan Pupuk Organik dari Urin Sapi" telah dilaksanakan dan berjalan lancar. Kegiatan penyuluhan ini sangat diterima dan warga masyarakat Desa Bonjoklor sangat berantusias dengan program ini. Karena dengan kegiatan tersebut, masyarakat bisa memanfaatkan limbah urin sapi selain bermanfaat bagi tanaman juga dapat menambah perekonomian masyarakat.
\end{abstract}

Kata kunci: Pupuk organik cair, Urin sapi, Molases, EM4

\section{Village Community Empowerment: Socialization of Organic Fertilizer Making Made from Cow Cattle Urine Raw}

\begin{abstract}
Cow urine has not been developed much to have beneficial values. The urine from cattle contains several nutrients, such as carbon $(C)$, oxygen $(O)$, hydrogen $(H)$, nitrogen $(N)$, phosphorus $(P)$, potassium $(K)$, magnesium $(\mathrm{Mg}$ ), and iron $(\mathrm{Fe})$. These contents are very much needed for plants, especially in Bonjoklor village where the majority of work is farming or farming. The objectives of the extension activity for making organic fertilizer from cow urine include: 1) Preventing environmental pollution because urine that is not utilized optimally can cause various diseases such as dysentery and diarrhea in both livestock and humans. 2) Utilization of cow urine waste helps the economy of the surrounding community 3) Increase soil fertility because organic fertilizer from cow urine has a good long-term effect on the land of Bonjoklor Village. In the manufacture of liquid organic fertilizer from cow urine uses the fermentation method for about 3 weeks. The activity "Socialization of Making Organic Fertilizer from Cow Urine" has been carried out and is running smoothly. This extension activity was very welcome and the people of Bonjoklor Village were very enthusiastic about this program. Because with these activities, people can use cow urine waste besides being beneficial for plants, it can also increase the community's economy.
\end{abstract}

Keywords: Liquid organic fertilizer, Cow urine, Molasses, and EM4

Article Info: Submitted: 20/03/2018 | Revised: 27/04/2018 | Accepted: 18/06/2018 


\section{PENDAHULUAN}

Limbah ternak merupakan hasil ekskresi yang dikeluarkan dari tubuh hewan. Limbah peternakan dapat digolongkan menjadi dua yaitu limbah padat dan limbah cair. Limbah peternakan adalah semua buangan dari usaha peternakan yang bersifat padat, cair dan gas, (Soehadji, 1992 dalam Budi, 2014). Salah satu limbah ternak cair yang dapat dimanfaatkan sebagai pupuk organik adalah urin/air seni sapi. Urin atau air seni sapi merupakan sisa cairan metabolisme yang dilakukan oleh sapi. Kandungan urin sapi telah banyak diteliti oleh pakar di bidang peternakan. Menurut Lingga (1991) ternak sapi mengandung beberapa kandungan, yaitu Nitrogen (0,50\%), Fosfor (1,00\%), Kalium $(1,50 \%)$, dan air $(92 \%)$. Kandungan-kandungan tersebut sangat dibutuhkan bagi tanaman terlebih di desa Bonjoklor yang mayoritas pekerjaannya adalah bercocok tanam.

Desa Bonjoklor merupakan desa yang bertumpu di bidang peternakan, pertanian, dan perikanan. Di bidang peternakan dapat dilihat dari banyaknya warga yang memelihara sapi. Di desa Bonjoklor sendiri juga mempunyai kelompok ternak sapi yang bertempat di dusun Taman Sari. Namun, pemanfaatan di bidang limbah ternak sapi masih kurang.

Berdasarkan hasil observasi dan wawancara dengan Bapak Sugeng sebagai ketua kelompok ternak di dusun Taman Sari, didapatkan bahwa masyarakat masih kurang antusias dalam memanfaatkan limbah sapi. Di desa Bonjoklor sendiri pernah diberikan penyuluhan terkait pemanfaatan limbah sapi menjadi pupuk, dalam hal ini limbah yang dipakai adalah limbah padat sapi, namun terdapat beberapa kendala sehingga pembuatan pupuk dari limbah padat sapi tidak dapat diteruskan, yaitu bahan-bahan yang digunakan harganya kurang terjangkau, dan dalam pemeliharaannya membutuhkan tenaga yang ekstra karena dalam proses pengeluarannya limbah padat sapi tidak boleh tercampur dengan urin sapi.

Berdasarkan pemaparan di atas, maka kelompok $33 \mathrm{KKN}$ di desa Bonjoklor mengajukan program penyuluhan terkait pemanfaatan limbah ternak sapi yang difokuskan pada limbah cair sapi yaitu berupa urin sapi. Hal tersebut berdasarkan mudah dan terjangkaunya harga alat dan bahan yang digunakan dalam proses pembuatan pupuk urin sapi. Dari segi kadar haranya, pupuk kandang cair dariurin sapi memiliki kandungan hara yang lebih tinggi dibandingkan dengan kotoran padatannya (Lingga,1999). Luaran yang diharapkan dari program mampu meningkatkan perekonomian masyarakat Bonjoklor serta mampu meningkatkan kesuburan tanah di desa Bonjoklor.

\section{METODE}

Metode Kegiatan pengabdian kepada masyarakat dalam bentuk penyuluhan dan pelatihan, serta dialog interaktif atau diskusi. Kegiatan ini merupakan rangkaian kegiatan pengabdian kepada masyarakat yang didanai oleh LPPM Universitas Muhammadiyah Purworejo. Pelaksanaan kegiatan selama kegiatan KKN berlangsung. Kegiatan ini merupakan rangkaian kegiatan pengabdian kepada masyarakat yang diselenggarakan di Desa Bonjokolor. Pelaksanaan kegiatan ini pada saat kegiatan Kuliah Kerja Nyata Mahasiswa. Pelaksanaan pembuatan urin sapi pada minggu kedua di bulan Maret tepatnya hari Minggu, 11 Februari 2018, pukul 09.00 WIB. bertempat di balai desa Bonjoklor kecamatan Bonorowo. Mitra dalam kegiatan pengabdian ini adalah warga, kelompok tani, dan para remaja karang taruna Bonjoklor kecamatan Bonorowo. 
Prosedur pada kegiatan pengabdian ini adalah diawali dengan kegiatan observasi, kemudian pelaksanaan yang meliputi:

a. Sosialisasi tentang pupuk. Pada tahapan ini adalah penyuluhan tentang pentingnya pupuk bagi tanaman. Sebagai pembicara adalah Rina Widiastuti, S.Pt. M.Si. yang merupakan dosen program studi Peternakan. Bu Rina memberikan pengarahan bahwa pupuk merupakan media yang sangat penting untuk menyuburkan tanaman. Pupuk terdiri dari beberapa jenis salah satunya adalah organik, pupuk jenis ini dapat dibuat dari kotoran dan urin hewan ternak. Kemudian bu Rina menerangkan cara pembuatan pupuk menggunakan urin sapi. Pembuatannya adalah dengan cara mencampurkan urin sapi dengan EM4 dan Molases.

b. Latihan pembuatan pupuk urin sapi. Pada tahap ini meliputi latihan pembuatan pupuk organik cair dan latihan pembuatan pupuk cair.

Data pada kegiatan pengabdian ini diperoleh berdasarkan hasil diskusi dan tanya jawab yang dilaksanakan antara pemateri dengan mitra. Data yang telah diperoleh dari hasil praktik, pengamatan, hasil tanya jawab dan tanggapan dari seluruh peserta yang mengikuti kegiatan pengabdian, selanjutnya data tersebut kemudian dilakukan analisis dengan analisis deskriptif.

\section{HASIL DAN PEMBAHASAN}

Sebagai salah satu program unggulan dalam pelaksanaan kegiatan ini adalah sosialisasi pembuatan pupuk urin sapi, adapun mekanisme kerjanya diuraikan sebagai berikut:

a. Cara Pembuatan Pupuk Organik Cair

Pupuk organik cair merupakan salah satu jenis pupuk yang banyak beredar di pasaran. Pupuk organik cair kebanyakan diaplikasikan melalui daun atau disebut sebagai pupuk cair foliar yang mengandung hara makro dan mikro esensial (N, P, K, S, $\mathrm{Ca}, \mathrm{Mg}, \mathrm{B}, \mathrm{Mo}, \mathrm{Cu}, \mathrm{Fe}, \mathrm{Mn}$, dan bahan organik). Menurut Setiawan (2005) dalam pembuatan pupuk hal yang wajib diperhatikan adalah nilai unsur haranya. Unsur hara yang paling dibutuhkan oleh tanaman antara lain unsur Nitrogen $(\mathrm{N})$, fosfor $(\mathrm{P})$, dan kalium (K). Ketiga unsur hara ini sangat penting bagi perumbuhan tanaman. Pupuk organik cair selain dapat memperbaiki sifat fisik, kimia, dan biologi tanah, juga membantu meningkatkan produksi tanaman, meningkatkan kualitas produk tanaman, mengurangi penggunaan pupuk anorganik dan sebagai alternatif pengganti pupuk kandang (Sarjana Parman, 2007).

Pupuk organik cair mempunyai beberapa manfaat diantaranya adalah (Nur Fitri, Erlina Ambarwati, dan Nasih Widya, 2007):

1) Dapat mendorong dan meningkatkan pembentukan klorofil daun dan pembentukan bintil akar pada tanaman leguminosae sehingga meningkatkan kemampuan fotosintesis tanaman dan penyerapan nitrogen dari udara.

2) Dapat meningkatkan vigor tanaman sehingga tanaman menjadi kokoh dan kuat, meningkatkan daya tahan tanaman terhadap kekeringan, cekaman cuaca dan serangan patogen penyebab penyakit.

3) Merangsang pertumbuhan cabang produksi.

4) Meningkatkan pembentukan bunga dan bakal buah, serta

5) Mengurangi gugurnya daun, bunga dan bakal buah. 
Pemberian pupuk organik cair harus memperhatikan konsentrasi atau dosis yang diaplikasikan terhadap tanaman. Berdasarkan beberapa hasil penelitian menunjukkan bahwa pemberian pupuk organik cair melalui daun memberikan pertumbuhan dan hasil tanaman yang lebih baik daripada pemberian melalui tanah. Semakin tinggi dosis pupuk yang diberikan maka kandungan unsur hara yang diterima oleh tanaman akan semakin tinggi, begitu pula dengan semakin seringnya frekuensi aplikasi pupuk daun yang dilakukan pada tanaman, maka kandungan unsur hara juga semakin tinggi. Namun, pemberian dengan dosis yang berlebihan justru akan mengakibatkan timbulnya gejala kelayuan pada tanaman Oleh karena itu, pemilihan dosis yang tepat perlu diketahui oleh para peneliti maupun petani dan hal ini dapat diperoleh melalui pengujian-pengujian di lapangan (Abdul Rahmi \& Jumiati, 2007).

b. Pembuatan Pupuk Cair

Pupuk cair adalah pupuk yang berbentuk cairan, dibuat dengan cara melarutkan kotoran ternak, daun jenis kacang-kacang dan rumput jenis tertentu ke dalam air. Pupuk cair mengandung unsur-unsur hara yang dibutuhkan untuk pertumbuhan, perkembangan, kesehatan tanaman. Unsur-unsur hara itu terdiri dari: Unsur Nitrogen $(\mathrm{N})$, untuk pertumbuhan tunas, batang dan daun. Unsur Fosfor $(\mathrm{P})$, untuk merangsang pertumbuhan akar buah, dan biji. Unsur Kalium (K), untuk meningkatkan ketahanan tanaman terhadap serangan hama dan penyakit. Pupuk cair ini memiliki keistimewaan yaitu pupuk ini dibanding dengan pupuk alam yang lain (pupuk kandang, pupuk hijau dan kompos) lebih cepat diserap tanaman. Berikut akan diuraikan alat-alat dan bahan yang diperlukan untuk pembuatan pupuk organik cair:

a) Alat - Alat:

(1) Drum/ember atau wadah lain untuk membuat pupuk cair.Bila menggunakan drum akan memperoleh pupuk cair sebanyak 100 liter.Pupuk dari bahan daundaunan, dapat memupuk tanaman di lahan seluas 100 m2.Pupuk dari bahan kotoran hewan, dapat memupuk tanaman di lahan seluas $200 \mathrm{~m} 2$.

(2) Karung beras/goni/plastik/nila, atau lainnya sebagai tempat bahan pupuk cair. Air dapat meresap ke dalam pori-pori karung tersebut dan bahan dalam karung tidak bisa keluar.

(3) Penutup drum/plastik hitam atau tutup lain, supaya sinar matahari maupun air hujan tidak dapat masuk ke dalam drum/wadah.

(4) Tali pengikat, untuk mengikat ujung karung sehingga bahan dalam karung tidak bisa keluar.

(5) Batu untuk pemberat,supaya karung dapat tenggelam.

b) Cara Pembuatan:

(1) Tempat yang dekat dengan sumber air dan tidak terkena panas sinar matahari serta hujan sangat baik untuk membuat pupuk cair.

(2) Isi karung dengan daun-daunan (yang telah dicincang halus) atau kotoran ternak yang masih segar (kira-kira 3/4 karung) lalu ikat karungnya. 
(3) Masukan karung berisi dedaunan dan kotoran tersebut ke dalam drum kosong/ ember, kemudian diisi air. Perbandingan antara air dengan berat isi karung adalah 2 liter air untuk $1 \mathrm{~kg}$ berat isi karung.

(4) Letakkan batu yang cukup berat di atas karung, sehingga karung tersebut dapat tenggelam. Drum dijaga selalu tertutup, agar tidak ada unsur hara yang hilang akibat penguapan.

(5) Karung diangkat dari dalam drum setelah kira-kira 2-3 minggu (bila menggunakan daun muda bisa 3 malam). Larutan dalam drum itulah yang disebut dengan pupuk cair. Ampasnya yang di dalam karung dapat digunakan untuk menyuburkan tanah. (http://www.heiferindonesia.org.)

c) Cara Penggunaan pupuk organik cair dijelaskan sebagai berikut:

Pengenceran : Agar tidak terlalu kental, pupuk cair perlu dicampur dengan air. Bila bahannya berasal dari daun, perbandingan adalah 1 bagian pupuk cair dan 3 bagian air. Bila bahannya berasal dari kotoran ternak, perbandingannya adalah 1 bagian pupuk cair dan 4-6 bagian air.

Penyiraman : Siram tanaman yang akan di pupuk 2-3 minggu setelah berkecambah, dan pemupukan dilakukan setiap 3 minggu.

Penggunaan dosis pupuk organik cair dengan teknologi unggulan, berkualitas tinggi yang merupakan hasil ekstraksi dari berbagai bahan organik yang diproses dengan bioteknologi tinggi yang mengandung banyak unsur makro dan mikro. Agar tujuan pemupukan tercapai, pupuk harus diaplikasikan secara tepat. Dalam pemupukan, ada beberapa hal penting yang harus diperhatikan, diantaranya adalah jenis tanaman yang akan dipupuk, jenis pupuk yang digunakan, dan waktu pemberian yang tepat. Jika ketiga hal ini terpenuhi, maka efisiensi dan efektivitas pemupukan akan tercapai. Pupuk yang digunakan harus sesuai dengan jenis dan kondisi tanaman (Arfiani, dkk. 2014). Jika limbah peternakan urin sapi diolah menjadi pupuk organik mempunyai efek jangka panjang yang baik bagi tanah, yaitu dapat memperbaiki struktur kandungan organik tanah karena memiliki bermacam-macam jenis kandungan unsure hara yang diperlukan tanah, selain itu juga menghasilkan produk pertanian yang aman bagi kesehatan (Affandi,2008). Dalam hal ini Sutato, (2002) menyatakan, bahwa pupuk organik cair dari urin sapi ini merupakan pupuk yang berbentuk cair tidak padat yang mudah sekali larut pada tanah dan membawa unsurunsur penting guna kesuburan tanah. Namun, pupuk organik cair dari urine sapi perah ini juga memiliki kelemahan, yaitu kurangnya kandungan unsur hara yang dimiliki jika dibandingkan dengan pupuk buatan dalam segi kuantitas.

Pelaksanaan pembuatan urin sapi pada minggu kedua di bulan Maret tepatnya hari Minggu, 11 Februari 2018, pukul 09.00 WIB. bertempat di balai desa Bonjoklor kecamatan Bonorowo. Acara tersebut dihadiri sekitar 60 orang yang tidak lain adalah bapak Kepala Desa yaitu bapak Sadar, perangkat desa, warga yang memiliki kelompok sapi, pemateri, dan mahasiswa KKN. Sebelum acara dimulai terlebih dahulu para hadirin menyanyikan lagu kebangsaan Indonesia Raya. 


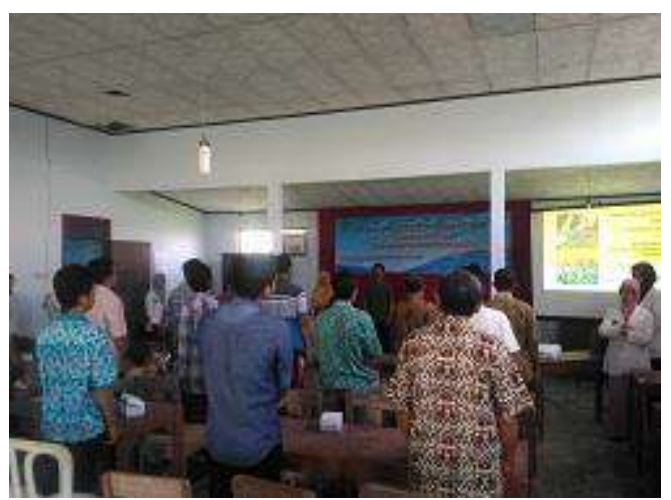

Gambar 1. Dokumen Pembukaan Menyanyikan Indonesia Raya

Gambar 1 memnunjukkan seluruh hadirin berdiri ketika menyanyikan lagu kebangsaan Indonesia Raya. Hal tersebut rutin dilakukan apabila sedang ada acara-acara resmi. Setelah selesai menyanyikan lagu kebangsaan, acara dibuka dengan membaca basmalah bersama lalu diikuti dengan sambutan-sambutan. Sambutan yang pertama oleh ketua panitia program kerja pembuatan urin sapi yaitu Damar Sentiko Putro, sambutan yang kedua oleh bapak Kepala Desa yaitu bapak Sadar, sambutan yang terakhir oleh Pemateri yaitu ibu Rina Widiastuti, S.Pt. M.Si.

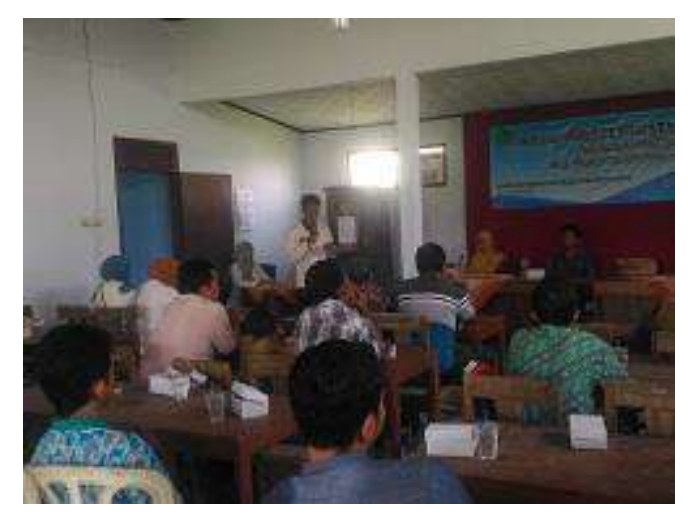

Gambar 2. Dokumen Kegiatan Sosialisasi

Pada gambar 2 dapat dilihat saat ketua panitia sosialisasi pembuatan pupuk urin sapi sedang memberikan sambutan kepada hadirin. Acara yang ketiga adalah materi oleh ibu Rina Widiastuti, S.Pt. M.Si. di sini warga yang mengikuti sosialisasi pembuatan pupuk urin sapi menyimak dengan tenang apa yang disampaikan oleh ibu Rina. Ibu Rina menjelaskan pentingnya pemupukan yang terdiri dari unsur hara Nitrogen, Phosphat, dan Kalium untuk membuat tanah menjadi subur. Beliau juga menjelaskan manfaat pupuk organik cair dari urin sapi, dan cara membuat pupuk organik cair yang berbahan dasar urin sapi. 


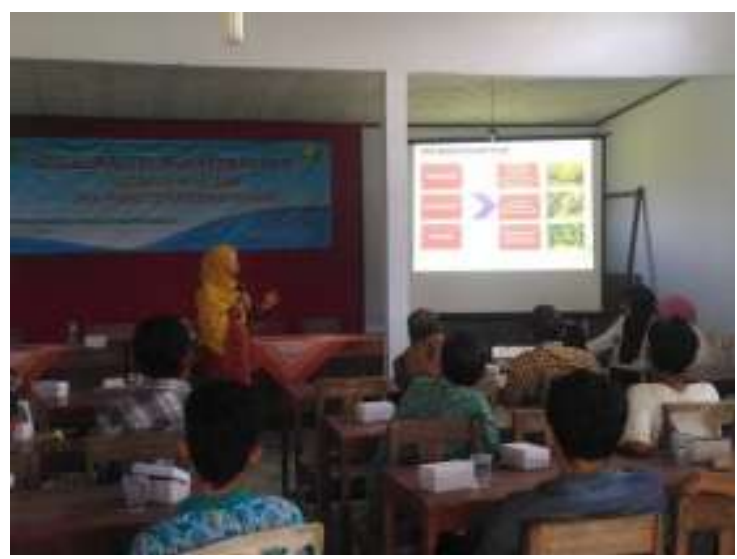

Gambar 3. Dokumentasi Pemberian Materi oleh Narasumber

Gambar 3 menunjukkan saat narasumber menyampaikan materi. Setelah itu ibu Rina mengajak warga untuk mempraktikkan cara membuat pupuk urin sapi dengan bahanbahannya yaitu urin sapi dengan kadar 100\% (25 lt.), Bio Activator (MOL/EM4) dengan kadar 1\% (0,25 lt.), dan Media Pakan MO (Molase) dengan kadar 2\% (0,5 lt.). Lalu, bahan-bahan dengan takaran tertentu dicampurkan lalu tutup dengan rapat dan difermentasikan selama 1-2 minggu untuk menjadi pupuk organik cair (POC) yang sempurna.

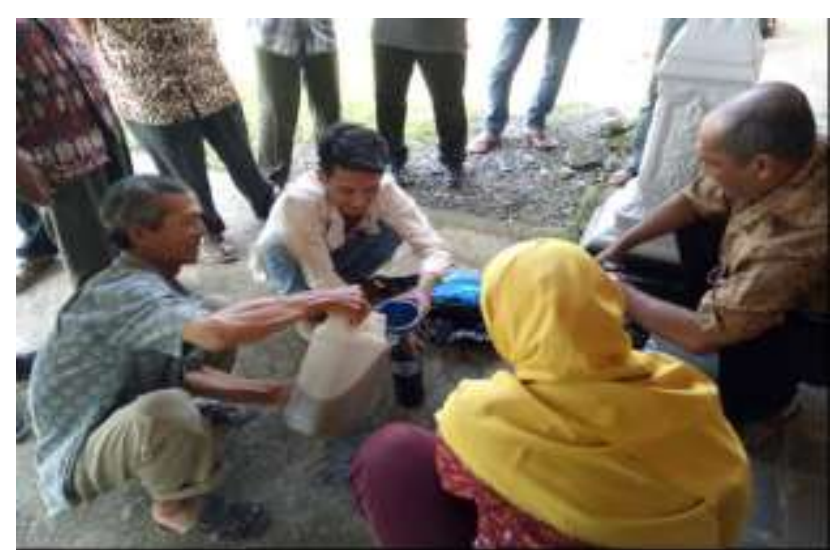

Gambar 4. Dokumentasi pelatihan Pembuatan Pupuk Organik Cair

Dapat dilihat pada Gambar 4 di atas saat proses membuat pupuk organik cair dari urin sapi Yang dilakukan oleh mahasiswa KKN dengan para kelompok tani. Dengan adanya praktik pembuatan secara langsung di hadapan para peserta diharapkan mampu memberikan gambaran pembuatan pupuk kepada peserta, sehingga diharapkan peserta akan mudah paham dengan segala macam prosesnya yang nantinya peserta data membuatnya secara mandiri.

Masyarakat desa Bonjoklor yang tadinya tidak terlalu antusias untuk membuat pupuk organik cair, tetapi saat pelaksanaan cara membuat pupuk organik cair yang relatif mudah dan bahan-bahannya yang tidak sulit untuk didapatkan, mereka menjadi tertarik dan antusias untuk membuat pupuk dari urin sapi. 


\section{KESIMPULAN}

Limbah merupakan material sisa yang tidak diinginkan setelah berakhirnya suatu proses. Sedangkan limbah ternak merupakan hasil ekskresi yang dikeluarkan dari tubuh hewan. Limbah peternakan dapat digolongkan menjadi dua yaitu limbah padat dan limbah cair. Salah satu limbah ternak cair yang dapat dimanfaatkan sebagai pupuk organik adalah urin/air seni sapi.

Limbah urin/air seni sapi memiliki kandungan yang sangat bermanfaat bila tanaman. Dalam proses pembuatannya, limbah ternah sapi dicampur dengan beberapa senyawa, yaitu EM4 dan Molases. Limah inilah yang disebut sebagai POC (Pupuk Organik Cair). Limbah ternak sapi ini memiliki beberapa keunggulan selain proses pembuatannya mudah dan alat serta bahan yang mudah ditemukan, limbah ini juga sangat mendukung bagi masyarakat pedesaan yang bekerja di bidang pertanian. Hal tersebut dikarenakan limbah pupuk organik cair ini mampu meningkatkan kemampuan fotosintesis tanaman dan penyerapan nitrogen dari udara, sehingga tanaman akan menjadi subur.

Kegiatan ini mendapat dukungan dari semua kalangan masyarakat di Desa Bonjoklor. Masyarakat sangat antusias dengan adanya program sosialisasi pembuatan pupuk cair dari urin sapi di desa Bonjoklor kecamatan Bonorowo kabupaten Kebumen. Selain mendapatkan ilmu dari program ini terkait pembuatan pupuk oragnik cair, masyarakat secara tidak langsung masyarakat juga terbantu dalam mengurangi pencemaran lingkungan akibat limbah urin sapi. Harapan dari kegiatan ini, selain member kebermanfaatnya dari segi kelimuan serta kesuburan tanaman, program ini diharapkan mampu menambah pendapatan masyarakat Desa Bonjoklor dari.

\section{DAFTAR PUSTAKA}

Affandi. (2008). Pemanfaatan urine Sapi yang Difermentasi sebagai Nutrisi Tanaman. Yogyakarta : andi offset

Ambarwati, Erlina, Nur Fitri Rizqiani dan Yuwono dan Nasih Widya. (2007). Pengaruh Dosis dan Frekuensi Pemberian Pupuk Organik Cair Terhadap Pertumbuhan dan Hasil Buncis (Phasheolus vulgaris L.) Dataran Rendah. Jurnal Ilmu Tanah dan Lingkungan.

Arfiani, Wan Barus, dkk. (2014). Respon Pertumbuhan Dan Produksi Kacang Hijau (Phaseolus Radiatus L.) Akibat Penggunaan Pupuk Organik Cair Dan Pupuk Tsp. Jurnal Ilmu Pertanian, 19(1): 1-11.

Djuarnani \& Setiawan. (2005). Cara Cepat Membuat Kompos. Agromedia Pustaka: Jakarta.

Lingga, P. 1999. Petunjuk Penggunaan Pupuk. PT.Penebar Swadaya. Jakarta.

Parman, Sarjana. (2007). Pengaruh Pertumbuha Pupuk Organic Cair Terhadap Pertumbuhan Tanaman Kentang (Solanum tuberosum L.). Semarang: Labolaratorium Biolagi Struktur Dan Fungsi Tumbuhan Jurusan Biologi Fakultas FMIPA UNDIP.

Rachman, Sutanto. (2002). Pertanian organik: Menuju Pertanian Alternatif dan Berkelanjutan. Jakarta:Kanisius

Rachman, Sutanto. (2002). Penerapan Pertanian Organik. Yogyakarta: Kanisius 
Rahmi, Abdul dan Jumiati. (2007). Pengaruh Konsentrasi dan waktu Penyemprotan Pupuk Organik Cair super Aci Terhadap Pertumbuhan dan Hasil Jagung Manis. Fakultas Pertanian Universitas Udayana. Denpasar.

Budi, Kun Rinekso, Endro Sutrisno, Sri Sumiyati. (2014). Studi Pembuatan Pupuk Organik Cair dari Fermentasi Urine Sapi (Ferisa) dengan Variasi Lokasi Peternakan yang Berbeda. Retrived from: http://eprints.undip.ac.id/42243/ 